\title{
Warming and oligotrophication cause shifts in freshwater phytoplankton communities
}

\author{
Laura Verbeek $^{1}$ (D) | Andrea Gall ${ }^{1} \mid$ Helmut Hillebrand $^{1,2}$ | Maren Striebel ${ }^{1}$
}

${ }^{1}$ Institute for Chemistry and Biology of the Marine Environment, University of Oldenburg, Wilhelmshaven, Germany

${ }^{2}$ Helmholtz Institute for Functional Marine Biodiversity at the University of Oldenburg (HIFMB), Oldenburg, Germany

\section{Correspondence}

Laura Verbeek, Institute for Chemistry and Biology of the Marine Environment, University of Oldenburg, Wilhelmshaven, Germany.

Email: laura.verbeek@uni-oldenburg.de

\section{Funding information}

Niedersächsisches Ministerium für Wissenschaft und Kultur; Bundesministerium für Bildung und Forschung

\begin{abstract}
While there is a lot of data on interactive effects of eutrophication and warming, to date, we lack data to generate reliable predictions concerning possible effects of nutrient decrease and temperature increase on community composition and functional responses. In recent years, a wide-ranging trend of nutrient decrease (re-oligotrophication) was reported for freshwater systems. Small lakes and ponds, in particular, show rapid responses to anthropogenic pressures and became model systems to investigate single as well as synergistic effects of warming and fertilization in situ and in experiments. Therefore, we set up an experiment to investigate the single as well as the interactive effects of nutrient reduction and gradual temperature increase on a natural freshwater phytoplankton community, using an experimental indoor mesocosm setup. Biomass production initially increased with warming but decreased with nutrient depletion. If nutrient supply was constant, biomass increased further, especially under warming conditions. Under low nutrient supply, we found a sharp transition from initially positive effects of warming to negative effects when resources became scarce. Warming reduced phytoplankton richness and evenness, whereas nutrient reduction at ambient temperature had positive effects on diversity. Our results indicate that temperature effects on freshwater systems will be altered by nutrient availability. These interactive effects of energy increase and resource decrease have major impacts on biodiversity and ecosystem function and thus need to be considered in environmental management plans.
\end{abstract}

\section{KEYWORDS}

biodiversity, climate change, evenness, oligotrophication, Planktotrons, regime shift, species richness, temperature increase, tipping point, warming

\section{1 | INTRODUCTION}

Anthropogenic actions cause numerous pressures and changes in ecosystems worldwide (Millennium Ecosystem Assessment, 2005), which endanger their stability (Ives \& Carpenter, 2007) and therefore eventually the goods and services these ecosystems provide for humanity (Costanza et al., 1997; Rockström et al., 2009). Many of these pressures-eutrophication (Schindler, 2006), loss of biodiversity (Cardinale et al., 2012), climate change-are global phenomena and affect all types of ecosystems (Rosenzweig et al., 2007; Walther et al., 2002). Freshwater systems, such as ponds, are especially susceptible to environmental changes as they are comparably small and variable in their morphology, and often undergo rapid changes in biodiversity and ecosystem functions (Adrian et al., 2009; Williamson, Dodds, Kratz, \& Palmer, 2008).

It remains uncertain to what extent changes in community composition directly translate into changes in ecosystem function. Ecosystem functions, such as total biomass production, are calculated as the sum of all individual species performances combined 
(Nijs \& Impens, 2000). Continuous levels of ecosystem function are usually maintained through species asynchrony (Hautier et al., 2014), but this may be disrupted through pulsed disturbances that synchronize species patterns, or through extinctions that reduce the pool of contributing species (Larsen, Williams, \& Kremen, 2005). Not all species contribute to all ecosystem functions equally (Hector \& Bagchi, 2007; Lefcheck et al., 2015; Shurin, Clasen, Greig, Kratina, \& Thompson, 2012), so that the consequences of a reduction in biodiversity depend both on the function and species in question. In general, the maintenance of multiple functions ("functional integrity") requires higher diversity than any single ecosystem function alone (Gamfeldt \& Hillebrand, 2008; Hector \& Bagchi, 2007; Isbell et al., 2011). As an exemplary ecosystem function, we studied the change in resource use efficiency (RUE, the amount of biomass per unit resource) in relation to nutrient decrease and warming.

Increasing temperatures and changes in nutrient availability are two of the most pervasive abiotic pressures of the last decades (Pomati, Matthews, Jokela, Schildknecht, \& Ibelings, 2012; Tadonléké, 2010). In aquatic ecosystems, warming influences biogeochemical cycles and nutrient-, oxygen-, and $\mathrm{CO}_{2}$-availability (O'Reilly, Alin, Plisnier, Cohen, \& McKee, 2003). Mediated through these abiotic responses, species' physiology, and population dynamics are strongly influenced by temperature (Cardinale, 2011; Striebel, Schabhüttl, Hodapp, Hingsamer, \& Hillebrand, 2016); consequently, warming is poised to alter communities and whole ecosystems. Compared to marine phytoplankton, most freshwater algae are adapted to higher temperatures $\left(10-30^{\circ} \mathrm{C}\right)$ (Butterwick, Heaney, \& Talling, 2005), with differences between species and taxa: optimal temperatures reported for diatoms range between $5-25^{\circ} \mathrm{C}$ (Butterwick et al., 2005; Soulsby, Houston, Montgomery, Surukip, \& Takahashi, 1981), for cyanobacteria between $25-30^{\circ} \mathrm{C}$ (Jöhnk et al., 2008; Lürling, Eshetu, Faassen, Kosten, \& Huszar, 2013), and for chlorophytes optimal temperatures range up to $30^{\circ} \mathrm{C}$ (Butterwick et al., 2005). Although warming of freshwater systems rarely exceeds the fundamental niche of phytoplankton, the different temperature optima of the various taxonomic groups will induce changes in dominance toward better adapted species (Kosten et al., 2012) at the expense of groups less competitive at higher temperatures (Rosset, Lehmann, \& Oertli, 2010).

The precise effects of warming will depend on interactive effects with other factors, for example, $\mathrm{pH}$ or nutrient availability. Regarding nutrient availability, an increase in temperature changes the physiological requirements of phytoplankton toward lower phosphorus and higher nitrogen content (Cotner, Makino, \& Biddanda, 2006; Toseland et al., 2013; Yvon-Durocher, Dossena, Trimmer, Woodward, \& Allen, 2015), potentially switching the system from $\mathrm{P}$ - to $\mathrm{N}$-limitation (Gilbert, 2013). Most studies addressing the interaction between warming and altered nutrient requirements focused on high nutrient conditions, revealing synergistic effects of eutrophication and warming (Heino, Virkkala, \& Toivonen, 2009; Moss et al., 2003; Rosset et al., 2010). These nutrient-warming interactions may strongly differ in oligotrophic systems, where temperature-dependent nutrient requirements are not easily met by availability. However, few studies explicitly addressed warming effects under lowered nutrient conditions (De Senerpont Domis, Van De Waal, Helmsing, Van Donk, \& Mooij, 2014; Velthuis et al., 2017).

Due to the widespread re-oligotrophication of freshwater systems, the interaction between nutrient limitation and warming is of increased importance (Jeppesen et al., 2005): Globally, eutrophication of freshwater systems has been identified as a severe ecological and economic problem, initializing efforts to reduce nutrient (mainly phosphorus) loading originating from washing detergents and agricultural fertilizers. Targeted management strategies have been devised and implemented in the 1970s and 1980s and efforts to avoid new influx and to reduce already present nutrient loadings have been successful. Consequently, phosphorous concentrations in many lakes have declined immensely (Anneville, Gammeter, \& Straile, 2005; Pomati et al., 2012; Van Donk et al., 2008). This has, for example, been well studied in Lake Biwa, Japan, for which both biotic and abiotic variables have been tracked over 32 years, showing an increase in nutrient loading in the 1960s and 1970s, followed by a decline during the 1980s, when management practices showed effect (Hsieh et al., 2010; Tsai et al., 2014). High nutrient concentrations are often characterized by high biomass production by few dominant species (Borge et al., 2004), whereas re-oligotrophication increases species richness and community evenness (Pomati et al., 2012) coupled with a decrease in autotrophic productivity or standing stocks (Finger, Wuest, \& Bossard, 2013; Verbeek et al., 2018).

Thus, in nutrient reduced systems, we expect different mechanisms shaping the temperature-productivity relationship, partly through direct physiological responses, partly through altered community composition and dominance in eutrophic and oligotrophic systems, respectively.

To test the effects of oligotrophication and warming, as well as their interaction, on the productivity and diversity of a natural phytoplankton community, we performed a controlled indoor mesocosm experiment. Treatments were chosen based on a field study of small farmland ponds in Belgium (Verbeek et al., 2018), which revealed a strong decrease in nutrient loading over time (especially for phosphorus) with significant change in phyto- and zooplankton biomass and composition. Using an indoor mesocosm facility comprising 12 so-called Planktotrons (Gall et al., 2017), we manipulated temperature (either constant at $20^{\circ} \mathrm{C}$ or increasing by $2^{\circ} \mathrm{C}$ per week for a total experiment duration of 7 weeks) and nutrient availability (either ambient or gradually decreasing by $20 \%$ per week) in a factorial design. The inoculum for the experiment was a natural phytoplankton community from one of the ponds in Belgium. We used $20^{\circ} \mathrm{C}$ as "ambient" treatment, as it was close to the ambient temperature at the time of the experiment and is a common temperature for the small farmland ponds particularly in early spring, partially due to their low depth (Staehr \& Sand-Jensen, 2006) in the region where we took the inoculum. We chose to increase the temperature by $2^{\circ} \mathrm{C}$ weekly, as this allowed for changes in species abundance in response to the temperature increase but avoided heat shocks. This reflects natural conditions as field data show that temperatures in ponds can increase by $2^{\circ} \mathrm{C}$ or more in the course of 1 week during spring (Berger et al., 2007; Huesemann et al., 2016). Phytoplankton species are 
able to acclimate to changes in water temperature in the timeframe of a few generations (Coles \& Jones, 2000; Staehr \& Sand-Jensen, 2006). While our final temperature of $32^{\circ}$ is rarely achieved in temperate ponds, it is nevertheless not completely outside of the temperature range of some algae, in particular cyanobacteria or green algae (which are the dominant group in our experimental community), which can have their temperature optimum at $26^{\circ} \mathrm{C}, 35^{\circ} \mathrm{C}$ or in some cases even higher (Coles \& Jones, 2000; Yentsch, 1974). The nutrient reduction was $20 \%$ per week in the oligotrophication treatments, whereas the treatments with constant nutrient supply were replenished with $20 \%$ of the original nutrient content weekly to maintain constant nutrient conditions. These two nutrient scenarios were chosen to provide a substantial, but not too rapid decrease in nutrient availability for the oligotrophication treatment, and to reflect semi-continuous conditions by the regular exchange in medium for the constant treatment.

Throughout the experiment, we monitored community composition, biomass, and resource use efficiency of the community to test the following hypotheses:

$\mathrm{H} 1$ : Increasing temperatures and nutrient reduction have interactive effects on algal biomass production. We expect an initial increase in biomass as nutrient supply is high, with the rate of increase being higher at a higher temperature (Figure 1). After the initial growth phase, the control (constant nutrient, no warming) will progress to carrying capacity, whereas the oligotrophication treatment without warming will show decreasing biomass with progressing nutrient loss. For the warming treatments, we expect significant temperature $\times$ nutrient interactions: as soon as warming exceeds threshold temperatures, biomass production potentially declines, with the onset of the decline being earlier with lowered nutrient availability. Thus, we expect a change in the sign of the warming effect over time from an increase in the initial biomass production rate compared to the control (positive effects of warming with high nutrient availability) to a decrease under progressing oligotrophication (negative effects of warming with nutrient deficiency).H2: Algal resource use efficiency (RUE = biomass production per unit resource available) will increase with oligotrophication which is expected to directly reduce excess nutrient supply and indirectly increase RUE by increasing biodiversity (Filstrup, Hillebrand, Heathcote, Harpole, \& Downing, 2014; Ptacnik, Solimini, et al., 2008). Consequently, we also expect algal C:nutrient ratios to be altered by both oligotrophication (altered supply of $\mathrm{N}$ and $\mathrm{P}$ ) and temperature (altered demand for $\mathrm{N}$ and P).H3: As the system is isolated without immigration, the initial diversity of the phytoplankton assemblage will be reduced over time in all treatments (Figure 1). We expect more rapid competitive dominance and exclusion with warming in the closed settings of our experiment (Hillebrand, Burgmer, \& Biermann, 2012) leading to reduced species richness and evenness (Figure 1 ). Reversing the predictions from eutrophication scenarios (Hillebrand et al., 2007), reduced nutrient conditions will show higher diversity (species richness and evenness) than the nutrient constant controls. We expect a significant nutrient $\times$ temperature interaction, as we foresee that reduced nutrient supply mitigates the negative effect of warming on coexistence.

\section{MATERIALS AND METHODS}

\section{1 | Experimental setup}

The experiment was conducted in 12 custom-tailored, stainless steel indoor-mesocosms, the so-called Planktotrons located at the Institute for Chemistry and Biology of the Marine Environment (ICBM) in Wilhelmshaven, Germany (Gall et al., 2017). These tanks are $1.2 \mathrm{~m}$ high and have an inner diameter of $0.8 \mathrm{~m}$, resulting in a volume of $600 \mathrm{~L}$. Built-in rotors with silicon lips at the side, top, and bottom, gently rotate in the Planktotrons, to prevent wall growth during the experiment. To ensure homogeneous phytoplankton distribution as well as (a) Biomass

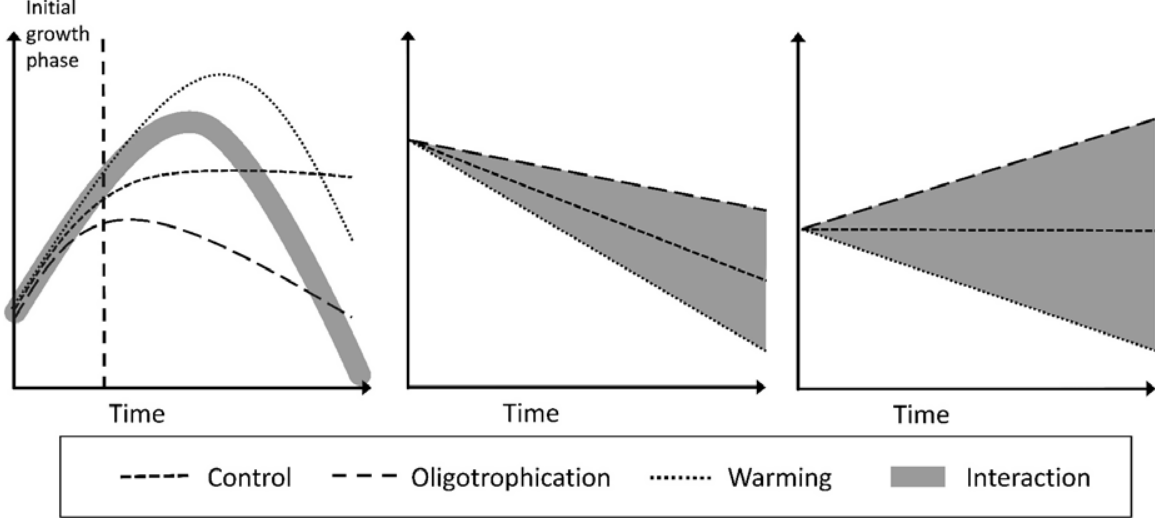

FIGURE 1 Expected dynamics over time for biomass, richness, and evenness of the phytoplankton community for the different treatments, temperature manipulation and changes in nutrient concentrations (full factorial design $2 \times 2$ temperature $\times$ nutrients) 
equal nutrient conditions throughout the water column, the mesocosms were manually mixed daily using a disk according to Striebel, Kirchmaier, and Hingsamer (2013).

The $2 \times 2$ factorial design was run in three replicates each: Two nutrient conditions, "constant nutrient concentrations" and "decreasing nutrient concentrations," and two temperature treatments, "ambient temperature" and "increasing temperature," resulted in a total of 12 experimental units. Treatments with "constant nutrient concentrations" were refilled after sampling (20\% exchange per week) with a medium including the initial nutrient concentrations. Treatments with "decreasing nutrient concentrations" were refilled with purified water, resulting in stepwise decreasing nutrient conditions. Temperature was kept constant at $20^{\circ} \mathrm{C}$ for "ambient temperature" treatments during the whole experiment (see Gall et al., 2017 for technical details), while for "increasing temperature" conditions the temperature was raised weekly after each sampling by $2^{\circ} \mathrm{C}$ (up to a maximum of $32^{\circ} \mathrm{C}$ during the last week of the experiment). The Planktotrons were filled with an artificial phytoplankton growth medium, according to the WC medium (Anderson, 2005), but with reduced nutrient concentrations resembling the nutrient conditions in the pond, the inoculum originated from (see below and Supporting Information Table S1). The $\mathrm{pH}$ was kept constant to avoid confounding effects (mean $7.7 \pm 0.37 \mathrm{SD}$ ) by adding TES buffer to the medium. Light conditions were kept constant during the experiment using a custom-tailored setup of LED lights. The intensity supplied at the water surface of the Planktotrons was $660 \mu \mathrm{mol}$ photons $\mathrm{m}^{-2} \mathrm{~s}^{-1}$ with 16:8 light-dark intervals.

A natural spring phytoplankton community from a eutrophic pond near Leuven in Belgium (Langerode Vijver, 50 $49^{\prime} 44.1^{\prime \prime} \mathrm{N} 4^{\circ} 38^{\prime}$ $\left.21.9^{\prime \prime} \mathrm{E}\right)$, prefiltered using a $20 \mu \mathrm{m}$ mesh screen to remove zooplankton, was used as inoculum. We focused on phytoplankton as the only trophic level because it is more likely to be affected by interactive effects of temperature and resource supply.

A total of $20 \mu \mathrm{m}$ mesh size was chosen after pre-experiments showed that larger mesh size did not remove all zooplankton, but $20 \mu \mathrm{m}$ caused no notable change in phytoplankton community composition based on microscopic determination. The exchanged amount of water was weekly controlled for zooplankton and was free of grazers throughout the entire experiment. All Planktotrons were inoculated with the same initial phytoplankton community and same nutrient conditions and started with equal temperature conditions $\left(20^{\circ} \mathrm{C}\right)$. The experiment was conducted for 44 days in total.

\subsection{Sampling and analyses}

In vivo chlorophyll $a$ concentrations were measured daily after mixing the Planktotrons using a handheld fluorometer (TURNER DESIGNS, AquaFluor ${ }^{\mathrm{TM}}$ ). Water temperature and light intensity were logged continuously in three Planktotrons using data loggers (Onset HOBO Pendant ${ }^{\circledR}$ data logger). All other parameters were measured weekly in association with the $20 \%$ medium renewal in each of the Planktotrons. Samples were taken after mixing the Planktotrons (according to Striebel et al., 2013) with disks (one specific disk per
Planktotron to avoid contamination) to ensure a homogeneous contribution within the water column. Water was removed from the top of the water column using beakers and the volume removed was determined and controlled by weighing the water. Samples for nutrient and pigment analyses and phytoplankton determination were bottled and processed immediately. Total phosphorus (TP) concentrations of samples were quantified by persulfate digestion followed by molybdate reaction (Wetzel \& Likens, 2000). Samples for particulate organic carbon (POC), nitrogen (PON), and particulate organic phosphorus (POP) were filtered onto precombusted and acid-washed glass-fiber GFC (Whatman) filters. Filters were stored at $-80^{\circ} \mathrm{C}$ until analysis. The $\mathrm{CN}$ elemental composition was measured with a $\mathrm{CHN}$ analyzer (Thermo, Flash EA 1112) and POP by molybdate reaction after sulfuric acid digestion (Wetzel \& Likens, 2000).

Phytoplankton samples for microscopic counts were fixed with $1 \%$ Lugol's iodine and counted using an inverted Leica DMIL LED microscope at $200 \times$ and $400 \times$ magnification (Utermöhl, 1958). Phytoplankton was counted up to at least 400 cells in total and cell volumes were calculated after approximation to the nearest geometric standard solid (Hillebrand, Dürselen, Kirschtel, Pollingher, \& Zohary, 1999). Biovolume proportions of species were used to calculate Pielou's Evenness (Pielou, 1966), additionally, we used richness as diversity estimate.

\section{3 | Data analysis}

Particulate organic carbon (measured through combustion, see above) and chlorophyll $a$ (measured in vivo with a fluorometer) as different proxies for phytoplankton biomass were highly correlated ( $\mathrm{C}$ Chl, $r=0.69, p<0.0001$ ), so we restricted our analysis to chlorophyll.

We used the nlme package in $\mathrm{R}$ to analyze our data. Using the Planktotron identity as a random variable, we performed an analysis separating the fixed effects of temperature and nutrient treatments (and their interaction) from the within-unit analysis of time and time $\times$ treatment effects. We used time as a categorical variable to allow for nonlinear dynamics within the Planktotrons.

Separate Linear Mixed Models (LMMs) were conducted for phytoplankton chlorophyll $a$ concentration, total biovolume, evenness, and richness. For phytoplankton, we also measured particulate nutrients ( $\mathrm{C}: \mathrm{N}$ as well as C:P, molar ratios). Correlations between resource use efficiency and diversity (species richness and Pielou's evenness) were assessed through ANOVAs of the final sampling day. In addition, we used resource use efficiency (RUE) (Filstrup et al., 2014; Ptacnik, Solimini, et al., 2008) as a proxy for ecosystem function to track the functional change in relation or reaction to species change. RUE was defined as unit biomass production in chlorophyll a $(\mu \mathrm{g} / \mathrm{L})$ per unit total phosphorus $(\mu \mathrm{g} / \mathrm{L})$.

All data were analyzed with $\mathrm{R}$ ( $\mathrm{R}$ Development Core Team \& $\mathrm{R}$ Core Team, 2013) using the packages vegan (Oksanen et al., 2013), MASS (Venables \& Ripley, 2002), lattice (Sarkar, 2008), ez (Lawrence, 2015), ggplot2 (Wickham, 2009), plyr (Wickham, 2011), reshape (Wickham, 2007), psych (Revelle, 2013), Isr (Navarro, 2015), nlme (Pinheiro, Bates, DebRoy, Sarkar, \& R Core Team, 2018), multcomp (Hothorn, Bretz, \& Westfall, 2008), and RColorBrewer (Neuwirth, 2014). 


\section{RESULTS}

\section{1 | Treatment effects on algal biomass}

Warming and nutrient depletion both had significant effects on algal biomass (significant temperature and nutrient main effects between subjects, LMM, Table 1). Chlorophyll a concentrations increased in all treatments within the first half of the experiment (Figure 2a). Especially in combination with warming, Chlorophyll $a$ concentrations increased further under constant nutrient concentrations. By contrast, biomass declined after 3 weeks in the nutrient depletion treatments, down to chlorophyll $a$ concentrations even lower than the initial concentrations (Figure 2a). Reflected by a significant time $\times$ temperature $\times$ nutrients interaction (LMM, Table 1), the initial positive effect of warming on biomass production turned later into a negative warming effect in the oligotrophication treatment, which resulted in a reduction in biomass below the level reached in the control and a hump-shaped distribution of algae biomass over time.

\section{2 | Treatment effects on resource use efficiency (RUE)}

RUE changed significantly over time during the experiment (LMM, significant effect of "time," Table 1). Treatment effects were characterized by a significant positive main effect of temperature between subjects and significant within-subject interactions of temperature $\times$ time as well as nutrient $\times$ time (Figure $2 b$, LMM, Table 1). While the resource use efficiency increased during the whole experimental period under high nutrient conditions, it followed a humpshaped pattern when decreasing nutrient concentrations and warming interacted (Figure 2b). Initially, RUE for warmed, nutrient-reduced mesocosm was higher than for any other treatment combination (though not significantly so) but decreased below the levels of both the control and the warming treatment with progressing nutrient depletion. At the end of the experiment, maximum RUE was obtained under warmed, constant nutrient conditions.

We did not find any significant effects on $\mathrm{C}: \mathrm{N}$ ratios throughout the experiment. C:P ratios significantly increased over time in all treatments (main effect of time, LMM, Table 1, Figure 2c, d), reflecting the incorporation of initially available nutrients in new production of biomass. Significant main effects of nutrients and significant interactions between nutrients $x$ time and nutrients $\times$ warming reflected that the C:P stoichiometry of phytoplankton was strongly tied to nutrient supply (Table 1). At day 44, C:P was more than twofold higher in the nutrient-depleted treatments compared to the nutrient constant treatments (Figure 2). Temperature effects on C:P dependent on nutrient supply (significant nutrients $\times$ temperature), with warming increasing C:P in nutrient-depleted mesocosms.

\section{3 | Treatment effects on phytoplankton biodiversity and composition}

In all treatments, we observed a decrease in species richness over time (LMM: significant effect of time, Table 1). This decrease was most pronounced in treatments where temperature was increased (Figure 2e), reflected by a significant temperature main effect and time $\times$ temperature interaction (LMM, Table 1). After an initial increase in the first 2 weeks of the experiment, evenness consistently decreased with increasing temperature, but remained high in the interaction treatment until the end of the experiment (Figure 2f). Consequently, temperature was both a significant main effect and a significant interactive effect with time for evenness in the LMM (Table 1). Nutrient effects on evenness were not significant (Table 1). We additionally tested if treatment-mediated effects on resource use efficiency were related to phytoplankton biodiversity at the end of the experiment, however, this was not the case (ANOVA, RUE vs. richness: $p=0.595$; RUE vs. Pielou's evenness: $p=0.129$ ).

By the end of the experiment, chlorophyte and cyanobacteria species dominated the communities, compared to a more balanced community at the start of the experiment (Figure 3). The species composition at the end of the experiment was highly dominated by a single species (Scenedesmus ecornis) in the gradually warmed treatments, while the abundances were more evenly distributed in the constant temperature treatments. This insight into species composition explains the strong decline in evenness in the warmed

TAB LE 1 Linear Mixed Models, transformations to ensure homogeneity of variance are given in the table. The table gives F-values for each test and denotes the $p$-values in brackets. Effects significant at $p<0.05$ are highlighted in bold

\begin{tabular}{|c|c|c|c|c|c|c|c|c|}
\hline Factor & $\mathrm{dfN}$ & $\mathrm{dfD}$ & Chl & RUE & $C: P$ & $\mathrm{C}: \mathrm{N}$ & Richness & Evenness \\
\hline Transformation & & & None & None & Log & None & None & None \\
\hline \multicolumn{9}{|l|}{ Between subjects } \\
\hline Nut & 1 & 8 & $23.79(0.001)$ & $0.95(0.358)$ & $27.83(<0.001)$ & $0.31(0.764)$ & $3.92(0.083)$ & 3.25 (0.109) \\
\hline Temp $\times$ nut & 1 & 8 & $0.02(0.893)$ & 2.19 (0.177) & $9.65(0.015)$ & $0.35(0.570)$ & $3.59(0.095)$ & $0.23(0.641)$ \\
\hline Time & 5 & 40 & $28.68(<0.001)$ & $38.14(<0.001)$ & $21.01(<0.001)$ & $1.62(0.176)$ & $28.92(<0.001)$ & $8.09(<0.001)$ \\
\hline Time $\times$ temp & 5 & 40 & $6.67(<0.001)$ & $3.81(0.006)$ & $0.39(0.848)$ & $0.44(0.819)$ & $10.79(<0.001)$ & $7.11(<0.001)$ \\
\hline Time $\times$ nut & 5 & 40 & $41.34(<0.001)$ & $6.17(<0.001)$ & $7.45(<0.001)$ & $1.26(0.300)$ & $1.25(0.306)$ & $1.07(0.391)$ \\
\hline Time $\times$ nut $\times$ temp & 5 & 40 & $4.04(0.005)$ & $0.92(0.480)$ & $1.64(0.17)$ & $0.22(0.953)$ & $0.05(0.998)$ & $1.65(0.170)$ \\
\hline
\end{tabular}


FIGURE 2 Phytoplankton community dynamics during the experiment. Chlorophyll a concentration ( $\mu \mathrm{g} / \mathrm{L})(\mathrm{A})$, resource use efficiency (RUE) (B), molar seston $\mathrm{C}: \mathrm{P}(\mathrm{C})$ and $\mathrm{C}: \mathrm{N}$ ratios $(\mathrm{D})$, species richness $(E)$ and Pielou's evenness $(F)$ over the duration of the experiment in days. The different treatments are differentiated through both shape and coloration: ambient temperature and constant nutrients as light gray dots, ambient temperature, and oligotrophication as gray squares, increased temperature and constant nutrients as charcoal diamonds and temperature increase with oligotrophication as black triangles. Data points mark sampling days and are shown as averages of the three replicates including error bars (SE). For C:P ratios one outlier has been excluded and two outliers for C:N ratios
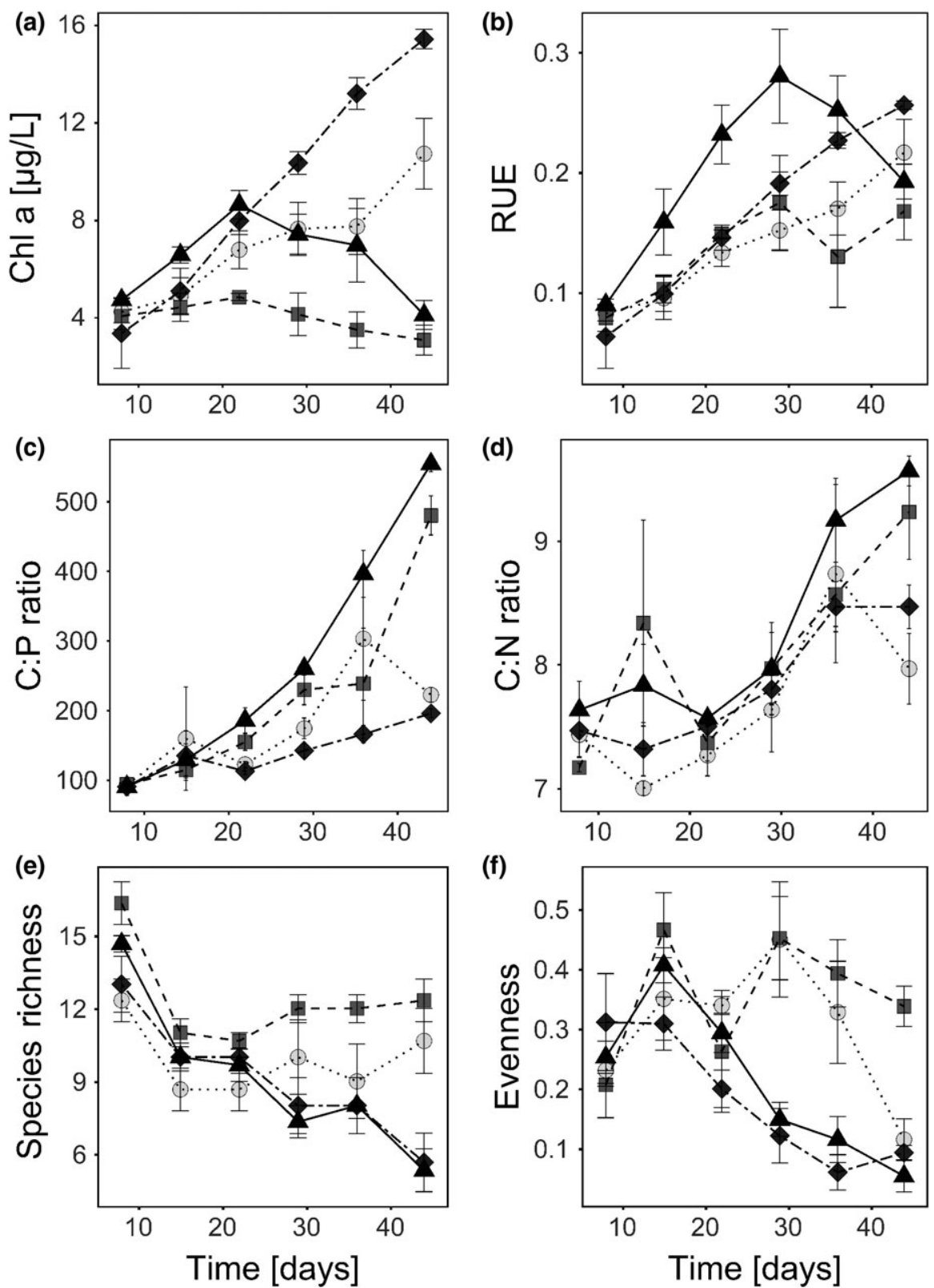

treatments and the $50 \%$ reduction in species richness at the end of the experiment, compared to the ambient temperature treatments. At ambient temperature with constant nutrients, Gonium pectorale dominated together with $S$. ecornis, whereas at ambient temperature and nutrient depletion, Pteromonas angulosa and Achroonema lentum contributed the largest proportion of biovolume (Figure 3).

\section{DISCUSSION}

\subsection{Temperature and nutrient effects on biomass (hypothesis H1)}

At the beginning of the experiment, biomass increased in all treatments reflecting the initial availability of light and nutrient. This initial increase was faster at increasing temperatures than at ambient temperature (Figure 2a), which reflects the positive effects of sublethal temperature increases on biochemical reactions and metabolism (Gillooly, Brown, West, Savage, \& Charnov, 2001). After 3 weeks, strong nutrient effects and nutrient $\times$ temperature interactions became apparent: in treatments with constant nutrient supply, biomass increased further during the whole experimental period (Figure 2a), whereas biomass decreased in the oligotrophication treatments during the second half of the experiment (Figure 2a). This corresponds to the expected relationship between realized production and resource availability (Gruner et al., 2008; Leibold, 1999). A further reduction in phytoplankton biomass under prolonged phases of oligotrophication can be expected in aquatic ecosystems. The trends in our experiment thus coincide with summer field observations in Belgian ponds over a 10-year sampling period (Verbeek et al., 2018), where nutrient availability in the investigated lakes 

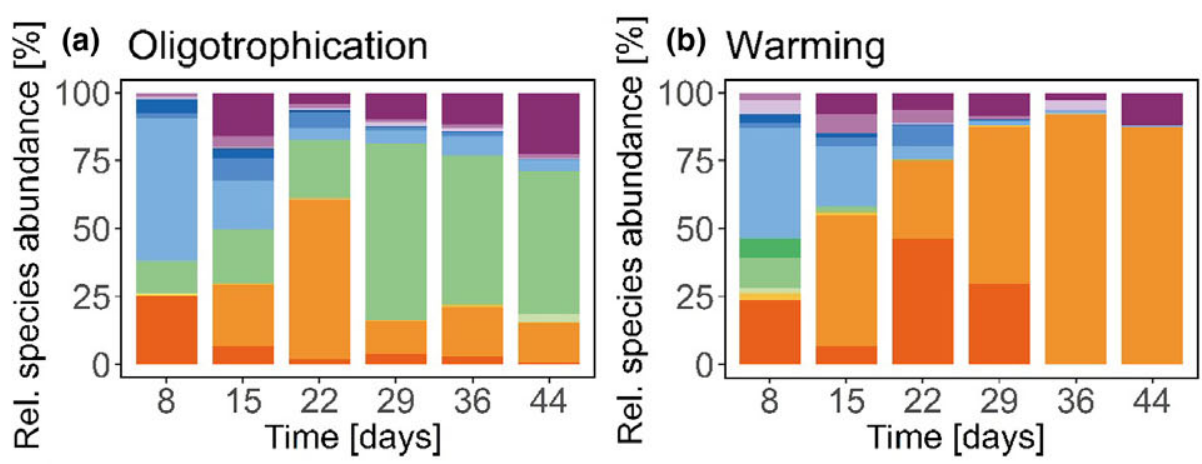

(c) Control

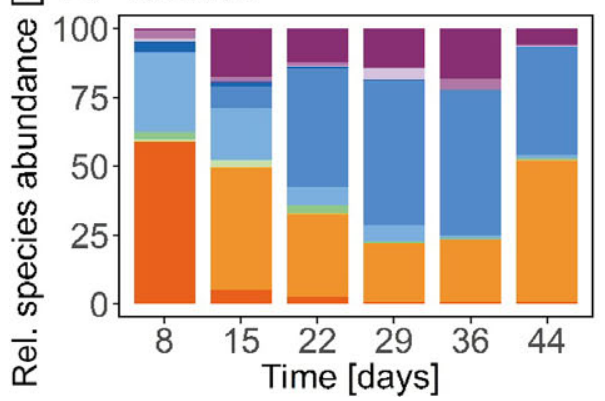

Achroonema.lentum

Asterionella.fomorsa

Chlamydomonas.sp.

Fragelaria.capucina

Gonium.pectorale

Monoraphidium.contortum

Mougetia.sp.

Pteromonas.angulosa

Scenedesmus.acuminatus

Scenedesmus.arcuatus

Scenedesmus.dimorphus

Scenedesmus.ecornis

Scenedesmus.quadricauda

Staurastrum.smithii

FIGURE 3 Change in relative species abundance in percent in the four treatments over time. Replicates were pooled and only species with at least $1 \%$ contribution at any one time are shown. Numbers are based on biovolume [Colour figure can be viewed at wileyonlinelibrary.com]

decreased between 2003 and 2013 (from $1.97 \pm 3.29 \mathrm{mg} / \mathrm{L}$ TP to $0.49 \pm 0.82 \mathrm{mg} / \mathrm{L}$ ), which was mirrored by a $71.5 \%$ decrease in phytoplankton biomass over the same period.

Most importantly, however, we found a clear interaction of warming and oligotrophication effects on algal biomass. At constant nutrient supply, temperature effects mediated between fast (warming) and a slow (ambient temperature) increase in biomass in the second half of the experiment, whereas at reduced nutrient supply, warming led to a substantial decrease in biomass by $50 \%$ in the second half of the experiment (Figure 2). Our study shows that warming enhances biomass production if nutrients are abundant, but a lack of nutrient supply might result in detrimental temperature effects. We suppose that warming is connected to enhance nutrient requirements associated with faster growth and if these demands cannot be met, biomass production is impaired.

This interaction between nutrient availability and temperature regime strongly points to an interdependency of energy and matter metabolism in the phytoplankton, as enhanced energy supply can only be converted into higher biomass production if essential resources are available. Namely through an increase in temperature, physiological processes such as photosynthesis, respiration, and protein synthesis are sped up as the rate of biochemical reactions increases. Without a sufficient supply of nutrients, the resulting increased demand for resources to maintain these processes and build necessary molecules and structures cannot be met. This points toward the fundamental links between fluxes of energy and materials in organisms based on the kinetics and elemental compositions of subcellular structures and processes (Allen \& Gillooly, 2009). These energy and matter links are well investigated for light versus nutrient effects (Sterner, Elser, Fee, Guildford, \& Chrzanowski, 1997; Urabe \& Sterner, 1996), but less so for temperature and nutrients. On a larger spatial and temporal scale, our results are reflected by a time series of Lake Biwa (Hsieh et al., 2010; Tsai et al., 2014). While our experiment can help to reveal the mechanistic background of changes, natural systems are usually subjected to more than two pressures. Ideally, experiments such as this should include data on the community change within the natural system the inoculum was taken from, so that it might be possible to distinguish to which extend the community was shaped by other environmental factors. Another aspect of natural systems not reflected in this experiment is the possibility for new species to immigrate and the subsequent turnover in species composition.

\section{2 | Treatment effects on ecosystem function, RUE, and stoichiometry (H2)}

We found greater resource use efficiency (RUE) with higher nutrient availability or temperature increase but no significant interactive effect, which is mostly in agreement with findings by De Senerpont Domis et al. (2014). In opposition to our results, some other studies have found that resource use efficiency would increase with lower nutrient availability (Bridgham, Pastor, Mcclaugherty, \& Richardson, 1995; Vitousek, 1982), but this might be due to different community composition and species-specific RUE. 
The opposing direction of the two pressures also explains the hump-shaped temporal dynamics of biomass production and RUE. It is possible that biomass and RUE would have declined even further, below the levels of the oligotrophic control over the next weeks, because the temperature stress had also diminished species richness. This increases the probability that the community had lost productive and/or efficient species as well as any buffering capacities of rare species (Corcoran \& Boeing, 2012). Without the chance to regain species through regional diversity by immigration (Hillebrand, Soininen, \& Snoeijs, 2010), an isolated ecosystem is severely changed and destabilized through the two pressures (Hillebrand et al., 2012). Our results of the interaction treatment could be an indication that ecosystem functions are destabilized in a major way through the interaction of both stressors.

We found a very strong increase in C:P ratios as well as a slight increase in $\mathrm{C}: \mathrm{N}$ ratios in all treatments, with a significantly higher increase in C:nutrient ratios in the oligotrophication treatments. C:nutrient ratios, in general, have been shown to increase with decreasing nutrient supply (Bridgham et al., 1995; Moreno \& Martiny, 2018; Vitousek, 1982) leading to lower food quality of primary producers, the basis of a food web. This can for example be caused by a decrease in nutrient levels in relation to biomass produced at higher metabolic rates at higher temperatures, or by a limitation of nutrient supply, such as phosphorus (Cross, Hood, Benstead, Huryn, \& Nelson, 2015). The effects of oligotrophication will therefore become more severe with increasing temperature. Given that oligotrophication is increasingly a phenomenon freshwater systems worldwide (Hsieh et al., 2010; Pomati et al., 2012), this has strong implications for higher trophic levels. Most herbivores are more constrained in their nutrient demands than phytoplankton and higher C:nutrient ratios mean lower food quality for the grazers. With lower food quality, the gross growth efficiency of the grazers decreases, leading to less biomass at higher trophic levels. This pattern is relevant in both aquatic and terrestrial systems (Elser et al., 2000). For the C: $\mathrm{N}$ ratio specifically, changes can mostly be explained by temperature effects: an increase in temperature increases the nitrogen-demand in the cells through, for example, higher protein assembly, but because carbon content increases simultaneously through higher biomass production, the $\mathrm{C}: \mathrm{N}$ ratio remains comparably constant (Cotner et al., 2006). The interaction between lower $\mathrm{N}$-supply and higher productivity then leads to the highest $\mathrm{C}: \mathrm{N}$ ratios being found in the interaction treatment where both mechanisms occur simultaneously. The effects were, however, not strong enough to be significant.

For the P-content of the cells, however, oligotrophication had stronger effects than temperature changes in our experiment. As phosphorous is considered to be the main limiting nutrient in many freshwater systems (but see Elser et al., 2007), the limitation becomes more severe with ongoing oligotrophication. Other studies, such as Van Donk et al. (2008) have found similar patterns of increasing $\mathrm{C}: \mathrm{P}$ ratios with decreasing resource availability. This trend continues upward into higher trophic levels, as higher organisms often have higher P-demand (e.g. for skeletal structures) and less possibility of stoichiometric flexibility (Elser et al., 2000).

\subsection{Temperature and nutrient effects on species richness and evenness $(\mathrm{H} 3)$}

Being disconnected from the regional species pool, initial species richness could only decline over time. While we see some loss of species in all treatments, the treatments with ambient temperature had continuously higher species richness than those with increased temperature (Figure 2e), and species loss was much stronger in the treatments with increased temperature. One explanation would be stronger interspecies competition for the limiting resources. Following this, we would expect faster competitive exclusion (Hillebrand, 2011; Hillebrand et al., 2012). Unless there is a possibility of new species immigrating into an ecosystem from a larger, regional metacommunity system, local extirpation means that many rare species are permanently lost, which endangers ecosystem function, goods, and services (Jain et al., 2014; Lyons, Brigham, Traut, \& Schwartz, 2005; Mouillot et al., 2013). If the system were part of a metacommunity, this would lead to higher turnover, but as we worked in closed systems the effect was merely species loss. It has been shown that low evenness and a strong dominance of single species and general loss of more rare species is correlated (Hillebrand, 2011). With continuing oligotrophication, there was less possibility of any one species out-competing all other species to the point of extinction, as it was unlikely that any one species could realize its full growth potential. Instead, there was strong competition for the limited available nutrients in a more balanced community in terms of abundance. Our results show the inverse effect of fertilization studies such as Ptacnik, Solimini, et al. (2008) or Gamfeldt and Hillebrand (2008) - instead of increasing nutrients resulting in decreasing evenness, we see an increase in evenness with decreasing nutrient loadings (Figure 2e).

In the treatments with increasing temperature, the decrease in species richness could be caused through only a few species being able to cope with the high temperature, as generally, the optimal temperature for phytoplankton is between $10-20^{\circ} \mathrm{C}$ (Butterwick et al., 2005; Jöhnk et al., 2008). However, even the highest temperatures reached in the experiment are unlikely to have been lethal for entire populations. Instead, species that were too far out of their optimal range to compete and went locally extinct. Hence, the best-adapted species could come to dominate the community (Jensen, Jeppesen, Olrik, \& Kristensen, 1994). This is supported by the community composition at the end of the experiment, as we found especially green algae dominating the warmed treatment which are considered to be better adapted to higher temperatures than for example diatoms (which are more abundant in the control). Following Litchman et al. (2015), this can be considered as a result of shifts in trait distribution. It may even become a global pattern with climate change, which favors species with wider temperature ranges or higher temperature optima, such as green algae and cyanobacteria species.

Although there was a trend toward higher RUE with lower diversity (data not shown) which is opposed to trends found in other studies, for example (Ptacnik, Lepistö, et al., 2008; Striebel et al., 2009), we did not see a significant change in resource use efficiency. Instead, we 
found high levels of biomass in the treatments with finally very low species numbers. This is in agreement with results from a study of 131 lakes (Filstrup et al., 2014), which shows a strongly negative relationship between community evenness and resource use efficiency. The reason might either be a sampling effect: fast-growing species adapted to high temperature were present and dominated the system, hence also the low evenness (Hillebrand et al., 2007, 2012), or an effect of selection: the species with the greatest competitive strength under the increasing stress conditions is also the one with highest resource use efficiency. This would result in both low evenness and high biomass production based on very little resources. More often, a decrease in diversity has been associated with a general decrease in ecosystem functionality as soon as more than a single function is considered (Gamfeldt, Hillebrand, \& Jonsson, 2008; Gamfeldt et al., 2013; Mouillot et al., 2013). To maintain a number of ecosystem functions multiple species with different traits are necessary (Hector \& Bagchi, 2007; Mouillot et al., 2013). However, to achieve high levels of a single function it is not necessary to have a large number of species (Moss, 2000). Regarding management practices, our results raise the question whether a decrease in nutrient input will be beneficial to desired ecosystem states such as high diversity. If a pond has been in a eutrophic state for long periods of time, the community is adapted to the high nutrient levels and (re) oligotrophication would act as a stressor, changing community composition and ecosystem functions. If dispersal from other diverse communities is limited, the change in abiotic environment is likely to decrease diversity and productivity of the original community, even more so with globally increasing temperatures.

Our experiment revealed an interdependency of the effects of warming and nutrient availability on phytoplankton biomass. The initial positive effects of temperature increase on biomass production remained positive if enough resources were available, but turned negative under decreasing nutrient supply through oligotrophication. This led to hump-shaped temporal patterns in biomass production, resource use efficiency and strong decreases in diversity measures. Oligotrophication allowed for a more even, species-rich community while increasing temperature stress resulted in a significant reduction in species richness and evenness. Particularly with ongoing problems like high global extinction rates, eutrophication, and climate change, it is necessary to understand what stabilizes an ecosystem and to find out which factors are the most important ones to assure the desired functions (e.g. conservation vs. high productivity, Moss, 2000).

\section{ACKNOWLEDGEMENTS}

The authors thank Heike Rickels and Silke Ammermann for technical support during laboratory analysis and Janna-Sophie Lemmel for help during the experiment as well as Matthias Vanhamel and Edwin van den Berg, who provided sampling support when we collected the initial community in Belgium. Furthermore, we thank Udo Uebel and Uwe Ebensen for technical support with the Planktotrons. This project was funded by BMBF via the BiodivERsA-Verbundvorhaben ERA-Net BiodivERsA project TIPPINGPOND. The establishment of the infrastructure was financed by the Lower Saxony Ministry for
Science and Culture (MWK) and the Institute for Chemistry and Biology of the Marine Environment. We also thank three anonymous reviewers for their helpful input and comments, which greatly improved this manuscript.

\section{CONFLICTS OF INTEREST}

The authors have no conflict of interest to declare.

\section{ORCID}

Laura Verbeek (iD http://orcid.org/0000-0002-1488-6522

\section{REFERENCES}

Adrian, R., Reilly, C. M. O., Zagarese, H., Baines, S. B., Hessen, D. O., Keller, W., ... Winder, M. (2009). Lakes as sentinels of climate change. Limnology and Oceanography, 54, 2283-2297.

Allen, A. P., \& Gillooly, J. F. (2009). Towards an integration of ecological stoichiometry and the metabolic theory of ecology to better understand nutrient cycling. Ecology Letters, 12, 369-384.

Anderson, R. A. (2005). Appendix - Recipes for freshwater and seawater media. In R. A. Anderson (Ed.), Algal culturing techniques (Vol. 53, 1st ed., pp. 1-596). Burlington, VA: Elsevier Academic Press.

Anneville, O., Gammeter, S., \& Straile, D. (2005). Phosphorus decrease and climate variability: Mediators of synchrony in phytoplankton changes among European peri-alpine lakes. Freshwater Biology, 50, 1731-1746.

Berger, S. A., Diehl, S., Stibor, H., Trommer, G., Ruhenstroth, M., Wild, A., ... Striebel, M. (2007). Water temperature and mixing depth affect timing and magnitude of events during spring succession of the plankton. Oecologia, 150, 643-654.

Borge, K., Hultmark, D., Clark, A. G., Rosbash, M., Spellman, P. T., Tzou, P., ... Zeng, Z. B. (2004). Impact of nitrogen deposition grasslands. Science, 303, 1876-1880.

Bridgham, S. D., Pastor, J., Mcclaugherty, C. A., \& Richardson, C. J. (1995). Nutrient-use efficiency: A Litterfall Index, a model, and a test along a nutrient- availability gradient in North Carolina. The American Naturalist, 145, 1-21.

Butterwick, C., Heaney, S. I., \& Talling, J. F. (2005). Diversity in the influence of temperature on the growth rates of freshwater algae, and its ecological relevance. Freshwater Biology, 50, 291-300.

Cardinale, B. J. (2011). Biodiversity improves water quality through niche partitioning. Nature, 472, 86-89.

Cardinale, B. J., Duffy, J. E., Gonzalez, A., Hooper, D. U., Perrings, C., Venail, P., ... Naeem, S. (2012). Biodiversity loss and its impact on humanity. Nature, 489, 326.

Coles, J. F., \& Jones, R. C. (2000). Effect of temperature on photosynthesis-light response and growth of four phytoplankton species isolated from a tidal freshwater river. Journal of Phycology, 36, 7-16.

Corcoran, A. A., \& Boeing, W. J. (2012). Biodiversity increases the productivity and stability of phytoplankton communities. PLoS ONE, 7, 1-9.

Costanza, R., Arge, R., De Groot, R., Farber, S., Grasso, M., Hannon, B., ... van den Belt, M. (1997). The value of the world's ecosystem services and natural capital. Nature, 387, 253-260.

Cotner, J. B., Makino, W., \& Biddanda, B. A. (2006). Temperature affects stoichiometry and biochemical composition of Escherichia coli. Microbial Ecology, 52, 26-33.

Cross, W. F., Hood, J. M., Benstead, J. P., Huryn, A. D., \& Nelson, D. (2015). Interactions between temperature and nutrients across levels of ecological organization. Global Change Biology, 21, 1025-1040. 
De Senerpont Domis, L. N., Van De Waal, D. B., Helmsing, N. R., Van Donk, E., \& Mooij, W. M. (2014). Community stochiometry in a changing world: Combined effects of warming and eutrophication on phytoplankton dynamics. Ecology, 95, 1485-1495.

Elser, J. J., Bracken, M. E. S., Cleland, E. E., Gruner, D. S., Harpole, W. S., Hillebrand, H., ... Smith, J. E. (2007). Global analysis of nitrogen and phosphorus limitation of primary producers in freshwater, marine and terrestrial ecosystems. Ecology Letters, 10, 1135-1142.

Elser, J. J., Fagan, W. F., Denno, R. F., Dobberfuhl, D. R., Folarin, A., Huberty, A., ... Sterner, R. W. (2000). Nutritional constraints in terrestrial and freshwater food webs. Nature, 408, 578-580.

Filstrup, C. T., Hillebrand, H., Heathcote, A. J., Harpole, W. S., \& Downing, J. A. (2014). Cyanobacteria dominance influences resource use efficiency and community turnover in phytoplankton and zooplankton communities. Ecology Letters, 17, 464-474.

Finger, D., Wuest, A., \& Bossard, P. (2013). Effects of oligotrophication on primary production in peri-alpine lakes. Water Resources Research, 49, 4700-4710.

Gall, A., Uebel, U., Ebensen, U., Hillebrand, H., Meier, S., Singer, G., ... Striebel, M. (2017). Planktotrons: A novel indoor mesocosm facility for aquatic biodiversity and food web research. Limnology and Oceanography: Methods, 15, 663-677.

Gamfeldt, L., \& Hillebrand, H. (2008). Biodiversity effects on aquatic ecosystem functioning - Maturation of a new paradigm. International Review of Hydrobiology, 93, 550-564.

Gamfeldt, L., Hillebrand, H., \& Jonsson, P. R. (2008). Multiple functions increase the importance of biodiversity for overall ecosystem functioning. Ecology, 89, 1223-1231.

Gamfeldt, L., Snäll, T., Bagchi, R., Jonsson, M., Gustafsson, L., Kjellander, P., .. Bengtsson, J. (2013). Higher levels of multiple ecosystem services are found in forests with more tree species. Nature communications, 4, 1340.

Gilbert, J. A. (2013). Biological oceanography: Some phytoplankton like it hot. Nature Climate Change, 3, 954-955.

Gillooly, J. F., Brown, J. H., West, G. B., Savage, V. M., \& Charnov, E. L. (2001). Effects of size and temperature on metabolic rate. Science, 293, 2248-2251.

Gruner, D. S., Smith, J. E., Seabloom, E. W., Sandin, S. A., Ngai, J. T., Hillebrand, H., ... Bolker, B. M. (2008). A cross-system synthesis of consumer and nutrient resource control on producer biomass. Ecology Letters, 11, 740-755.

Hautier, Y., Seabloom, E. W., Borer, E. T., Adler, P. B., Harpole, W. S. Hillebrand, H., ... Hector, A. (2014). Eutrophication weakens stabilizing effects of diversity in natural grasslands. Nature, 508, 521525.

Hector, A., \& Bagchi, R. (2007). Biodiversity and ecosystem multifunctionality. Nature, 448, 188-190.

Heino, J., Virkkala, R., \& Toivonen, H. (2009). Climate change and freshwater biodiversity: Detected patterns, future trends and adaptations in northern regions. Biological Reviews, 84, 39-54.

Hillebrand, H. (2011). Temperature mediates competitive exclusion and diversity in benthic microalgae under different $\mathrm{N}$ : P stoichiometry. Ecological Research, 26, 533-539.

Hillebrand, H., Burgmer, T., \& Biermann, E. (2012). Running to stand still: Temperature effects on species richness, species turnover, and functional community dynamics. Marine Biology, 159, 2415-2422.

Hillebrand, H., Dürselen, C.-D., Kirschtel, D., Pollingher, U., \& Zohary, T. (1999). Biovolume calculation for pelagic and benthic microalgae. Journal of Phycology, 35, 403-424.

Hillebrand, H., Gruner, D. S., Borer, E. T., Bracken, M. E., Cleland, E. E., Elser, J. J., ... Smith, J. E. (2007). Consumer versus resource control of producer diversity depends on ecosystem type and producer community structure. Proceedings of the National Academy of Sciences of the United States of America, 104, 10904-10909.
Hillebrand, H., Soininen, J., \& Snoeijs, P. (2010). Warming leads to higher species turnover in a coastal ecosystem. Global Change Biology, 16, 1181-1193.

Hothorn, T., Bretz, F., \& Westfall, P. (2008). Simultaneous inference in general parametric models. Biometrical Journal, 50, 346-363.

Hsieh, C. H., Ishikawa, K., Sakai, Y., Ishikawa, T., Ichise, S., Yamamoto, Y., ... Kumagai, M. (2010). Phytoplankton community reorganization driven by eutrophication and warming in Lake Biwa. Aquatic Sciences, 72, 467-483.

Huesemann, M., Crowe, B., Waller, P., Chavis, A., Hobbs, S., Edmundson, S., \& Wigmosta, M. (2016). A validated model to predict microalgae growth in outdoor pond cultures subjected to fluctuating light intensities and water temperatures. Algal Research, 13, 195-206.

Isbell, F., Calcagno, V., Hector, A., Connolly, J., Harpole, W. S., Reich, P. B., ... Loreau, M. (2011). High plant diversity is needed to maintain ecosystem services. Nature, 477, 199-202.

Ives, A. R., \& Carpenter, S. R. (2007). Stability and diversity of ecosystems. Science, 317, 58-62.

Jain, M., Flynn, D. F. B., Prager, C. M., Hart, G. M., Devan, C. M., Ahrestani, F. S., ... Naeem, S. (2014). The importance of rare species: A trait-based assessment of rare species contributions to functional diversity and possible ecosystem function in tall-grass prairies. Ecology and Evolution, 4, 104-112.

Jensen, J. P., Jeppesen, E., Olrik, K., \& Kristensen, P. (1994). Impact of nutrients and physical factors on the shift from cyanobacterial to chlorophyte dominance in shallow Danish lakes.pdf. Canadian Journal of Fisheries and Aquatic Sciences, 51, 1692-1699.

Jeppesen, E., Søndergaard, M., Jensen, J. P., Havens, K. E., Anneville, O., Carvalho, L., ... Winder, M. (2005). Lake responses to reduced nutrient loading - An analysis of contemporary long-term data from 35 case studies. Freshwater Biology, 50, 1747-1771.

Jöhnk, K. D., Huisman, J., Sharples, J., Sommeijer, B., Visser, P. M., \& Stroom, J. M. (2008). Summer heatwaves promote blooms of harmful cyanobacteria. Global Change Biology, 14, 495-512.

Kosten, S., Huszar, V. L. M., Bécares, E., Costa, L. S., van Donk, E., Hansson, L.-A., ... Scheffer, M. (2012). Warmer climates boost cyanobacterial dominance in shallow lakes. Global Change Biology, 18, 118126.

Larsen, T. H., Williams, N. M., \& Kremen, C. (2005). Extinction order and altered community structure rapidly disrupt ecosystem functioning. Ecology Letters, 8, 538-547.

Lawrence, M. A. (2015). ez: Easy analysis and visualization of factorial experiments. $R$ package. Retrieved from https://cran.r-project.org/pac kage $=\mathrm{ez}$

Lefcheck, J. S., Byrnes, J. E. K., Isbell, F., Gamfeldt, L., Griffin, J. N., Eisenhauer, N., ... Duffy, J. E. (2015). Biodiversity enhances ecosystem multifunctionality across trophic levels and habitats. Nature Communications, 6, 6936.

Leibold, M. A. (1999). Biodiversity and nutrient enrichment in pond plankton communities. Evolutionary Ecology Research, 1, 73-95.

Litchman, E., de Tezanos, P. P., Edwards, K. F., Klausmeier, C. A., Kremer, C. T., \& Thomas, M. K. (2015). Global biogeochemical impacts of phytoplankton: A trait-based perspective. Journal of Ecology, 103, 13841396.

Lürling, M., Eshetu, F., Faassen, E. J., Kosten, S., \& Huszar, V. L. M. (2013). Comparison of cyanobacterial and green algal growth rates at different temperatures. Freshwater Biology, 58, 552-559.

Lyons, K. G., Brigham, C. A., Traut, B. H. H., \& Schwartz, M. W. (2005). Rare species and ecosystem functioning. Conservation Biology, 19, 1019-1024.

Millennium Ecosystem Assessment. (2005). Ecosystems and human wellbeing: Synthesis (Vol. 5, pp. 1-100). Washington, DC: Island Press

Moreno, A. R., \& Martiny, A. C. (2018). Ecological stoichiometry of ocean plankton. Annual Review of Marine Science, 10, 43-69. 
Moss, B. (2000). Biodiversity in fresh waters - An issue of species preservation or system functioning? Environmental Conservation, 27, $1-4$.

Moss, B., Mckee, D., Atkinson, D., Collings, S. E., Eaton, J. W., Gill, A. B., ... Wilson, D. (2003). How important is climate? Effects of warming, nutrient addition and fish on phytoplankton in shallow lake microcosms. Journal of Applied Ecology, 40, 782-792.

Mouillot, D., Bellwood, D. R., Baraloto, C., Chave, J., Galzin, R., HarmelinVivien, M., ... Thuiller, W. (2013). Rare species support vulnerable functions in high-diversity ecosystems. PLoS Biology, 11, e1001569.

Navarro, D. (2015). Learning statistics with R: A tutorial for psychology students and other beginners (Version 0.5). Adelaide, SA: University of Adelaide.

Neuwirth, E. (2014). RColorBrewer: ColorBrewer palettes $R$ package. Retrieved from https://cran.r-project.org/package=RColorBrewer

Nijs, I., \& Impens, I. (2000). Underlying effects of resource use efficiency in diversity-productivity relationships. Oikos, 91, 204-208.

Oksanen, J., Blanchet, F. G., Kindt, R., Legendre, P., Minchin, P. R., O'Hara, R. B., ... Wagner, H. H. (2013). vegan: Community ecology package. R package version 2.0-8. Retrieved from http://CRAN.R-pro ject.org/package=vegan

O'Reilly, C. M. O., Alin, S. R., Plisnier, P.-D. D., Cohen, A. S., \& McKee, B. A. (2003). Climate change decreases aquatic ecosystem productivity of Lake Tanganyika, Africa. Nature, 424, 5-7.

Pielou, E. C. (1966). The measurement of diversity in different types of biological collections. Journal of Theoretical Biology, 13, 131-144.

Pinheiro, J., Bates, D., DebRoy, S., Sarkar, D., \& R Core Team. (2018). nlme: Linear and nonlinear mixed effects models. $\mathrm{R}$ package version 3. 1-137. Retrieved from https://CRAN.R-project.org/package=nlme

Pomati, F., Matthews, B., Jokela, J., Schildknecht, A., \& Ibelings, B. W. (2012). Effects of re-oligotrophication and climate warming on plankton richness and community stability in a deep mesotrophic lake. Oikos, 121, 1317-1327.

Ptacnik, R., Lepistö, L., Willén, E., Brettum, P., Andersen, T., Rekolainen, S., ... Carvalho, L. (2008). Quantitative responses of lake phytoplankton to eutrophication in Northern Europe. Aquatic Ecology, 42, 227 236.

Ptacnik, R., Solimini, A. G., Andersen, T., Tamminen, T., Brettum, P., Lepistö, L., ... Rekolainen, S. (2008). Diversity predicts stability and resource use efficiency in natural phytoplankton communities. Proceedings of the National Academy of Sciences of the United States of America, 105, 5134-5138.

R Development Core Team \& R Core Team. (2013). R: A language and environment for statistical computing. $R$ Foundation for Statistical Computing, 1, 409.

Revelle, W. (2013). psych: Procedures for psychological, psychometric, and personality research. Evanston, IL: Northwestern University.

Rockström, A., Steffen, J. W., Noone, K., Parsson, A., Chapin III, F. S., Lambin, E., ... Foley, J. (2009). Planetary boundaries: Exploring the safe operating space for humanity. Ecology and Society, 14, 32.

Rosenzweig, C., Casassa, G., Karoly, D. J., Imeson, A., Liu, C., Menzel, A., ... Tryjanowski, P. (2007). Assessment of observed changes and responses in natural and managed systems. In M. L. Parry, O. F. Canziani, J. P. Palutikof, P. J. van der Linden, \& C. E. Hanson (Eds.), Climate Change 2007: Impacts, Adaptation and Vulnerability. Contribution of Working Group II to the Fourth Assessment Report of the Intergovernmental Panel on Climate Change (pp. 79-131). Cambridge, MA: Cambridge University Press.

Rosset, V., Lehmann, A., \& Oertli, B. (2010). Warmer and richer? Predicting the impact of climate warming on species richness in small temperate waterbodies. Global Change Biology, 16, 23762387.

Sarkar, D. (2008). Lattice: Multivariate data visualization with R. New York, NY: Springer.
Schindler, D. W. (2006). Recent advances in the understanding and management of eutrophication. Limnology and Oceanography, 51, 356363.

Shurin, J. B., Clasen, J. L., Greig, H. S., Kratina, P., \& Thompson, P. L. (2012). Warming shifts top-down and bottom-up control of pond food web structure and function. Philosophical transactions of the Royal Society of London Series B, 367, 3008-3017.

Soulsby, P. G., Houston, M., Montgomery, H., Surukip, Y., \& Takahashi, M. (1981). Growth responses of several diatom species isolated from various environments to temperature. Journal of Phycology, 653, 880888.

Staehr, P. A., \& Sand-Jensen, K. A. J. (2006). Seasonal changes in temperature and nutrient control of photosynthesis, respiration and growth of natural phytoplankton communities. Freshwater Biology, 51, 249262.

Sterner, R. W., Elser, J. J., Fee, E. J., Guildford, S. J., \& Chrzanowski, T. H. (1997). The light: Nutrient ratio in lakes: The balance of energy and materials affects ecosystem structure and process. The American Naturalist, 150, 663-684.

Striebel, M., Bartholmé, S., Zernecke, R., Steinlein, C., Haupt, F., Diehl, S., $\&$ Stibor, H. (2009). Carbon sequestration and stoichiometry of motile and nonmotile green algae. Limnology and Oceanography, 54, 17461752.

Striebel, M., Kirchmaier, L., \& Hingsamer, P. (2013). Different mixing techniques in experimental mesocosms - Does mixing affect plankton biomass and community composition? Limnology and Oceanography: Methods, 11, 176-186.

Striebel, M., Schabhüttl, S., Hodapp, D., Hingsamer, P., \& Hillebrand, H. (2016). Phytoplankton responses to temperature increases are constrained by abiotic conditions and community composition. Oecologia, 182, 815-827.

Tadonléké, R. D. (2010). Evidence of warming effects on phytoplankton productivity rates and their dependence on eutrophication status. Limnology and Oceanography, 55, 973-982.

Toseland, A., Daines, S. J., Clark, J. R., Kirkham, A., Strauss, J., Uhlig, C., ... Mock, T. (2013). The impact of temperature on marine phytoplankton resource allocation and metabolism. Nature Climate Change, 3, 979-984.

Tsai, C. H., Miki, T., Chang, C. W., Ishikawa, K., Ichise, S., Kumagai, M., \& Hsieh, C. H. (2014). Phytoplankton functional group dynamics explain species abundance distribution in a directionally changing environment. Ecology, 95, 3335-3343.

Urabe, J., \& Sterner, R. W. (1996). Regulation of herbivore growth by the balance of light and nutrients. Proceedings of the National Academy of Sciences of the United States of America, 93, 84658469.

Utermöhl, H. (1958). Zur Vervollkommnung der quantitativen Phytoplankton-Methodik. Mitteilungen der internationalen Vereinigung für theoretische und angewandte Limnologie, 9, 1-38.

Van Donk, E., Hessen, D. O., Verschoor, A. M., \& Gulati, R. D. (2008). Re-oligotrophication by phosphorus reduction and effects on seston quality in lakes. Limnologica, 38, 189-202.

Velthuis, M., De Senerpont Domis, L. N., Frenken, T., Stephan, S., Kazanjian, G., Aben, R., ... Van de Waal, D. B. (2017). Warming advances top-down control and reduces producer biomass in a freshwater plankton community. Ecosphere, 8, e01651.

Venables, W. N., \& Ripley, B. D. (2002). Modern applied statistics with $S$ (4th ed.). New York, NY: Springer.

Verbeek, L., Vanhamel, M., Berg, E., Hanashiro, F. T. T., Gianuca, A. T., Striebel, M., ... De Meester, L. (2018). Compositional and functional consequences of environmental change in Belgian farmland ponds. Freshwater Biology, 63, 581-596.

Vitousek, P. M. (1982). Nutrient cycling and nutrient use efficiency. The American Naturalist, 119, 553-572. 
Walther, G., Post, E., Convey, P., Menzel, P., Parmesan, C., Beebee, T. J., ... Bairlein, F. (2002). Ecological responses to recent climate change. Nature, 416, 389-395.

Wetzel, R. G., \& Likens, G. (2000). Limnological analyses. New York, NY: Springer.

Wickham, H. (2007). Reshaping data with the reshape package. Journal of Statistical Software, 21, 1-20.

Wickham, H. (2009). ggplot2: Elegant graphics for data analysis. New York, NY: Springer.

Wickham, H. (2011). The split-apply-combine strategy for data analysis. Journal of Statistical Software, 40, 1-29.

Williamson, C. E., Dodds, W., Kratz, T. K., \& Palmer, M. A. (2008). Lakes and streams as sentinels of environmental change in terrestrial and atmospheric processes. Frontiers in Ecology and the Environment, 6, 247-254.

Yentsch, C. S. (1974). Some aspects of the environmental physiology of marine phytoplankton: A second look. Oceanography and Marine Biology - An Annual Review, 12, 41-75.
Yvon-Durocher, G., Dossena, M., Trimmer, M., Woodward, G., \& Allen, A. P. (2015). Temperature and the biogeography of algal stoichiometry. Global Ecology and Biogeography, 24, 562-570.

\section{SUPPORTING INFORMATION}

Additional supporting information may be found online in the Supporting Information section at the end of the article.

How to cite this article: Verbeek L, Gall A, Hillebrand H, Striebel M. Warming and oligotrophication cause shifts in freshwater phytoplankton communities. Glob Change Biol. 2018;24:4532-4543. https://doi.org/10.1111/gcb.14337 